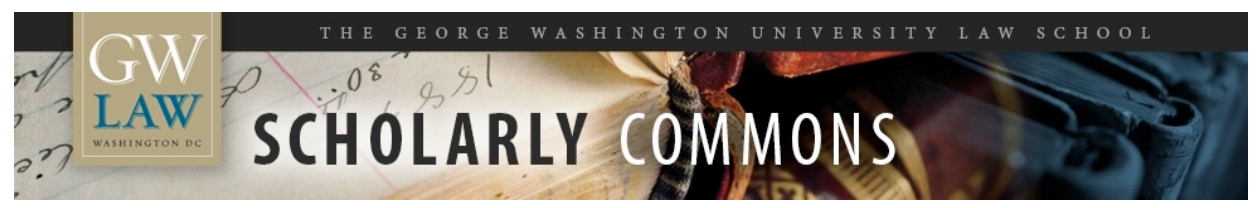

GW Law Faculty Publications \& Other Works

Faculty Scholarship

2019

Law and Norms in the Market Response to Discrimination in the Sharing Economy

Naomi Schoenbaum

Follow this and additional works at: https://scholarship.law.gwu.edu/faculty_publications

Part of the Law Commons 
Naomi Schoenbaum*

\title{
Law and Norms in the Market Response to Discrimination in the Sharing Economy
}

https://doi.org/10.1515/lehr-2019-0001

\begin{abstract}
Sharing-economy firms have opposed the application of antidiscrimination law to their transactions. At the same time, these firms have heralded their ability to achieve antidiscrimination aims without the force of law, and have adopted various measures to address discrimination. This Article documents and assesses these measures, focusing on the relationship between law and norms. Relying on the sharing economy as a case study, this Article shows how law can play a crucial role in spurring antidiscrimination efforts by firms that it does not regulate, but also how antidiscrimination law might nonetheless be undermined by these voluntary efforts.
\end{abstract}

Keywords: antidiscrimination law, sharing economy, norms, market, race, sex, equality

\section{Introduction}

Sharing-economy firms have objected strenuously to the application of antidiscrimination law to their transactions. ${ }^{1}$ At the same time, however, these firms have touted their ability to achieve antidiscrimination goals, ${ }^{2}$ and have

1 See, e.g. Michelle Chen, Does the Law Decide What Rights Are Afforded to Uber Drivers-or Does Uber? THE NATION (June 22, 2016), available at https://www.thenation.com/article/does-the-lawdecide-what-rights-are-afforded-to-uber-drivers-or-does-uber/; Claire Zillman, California's Uber Driver Decision Could Throw A Wrench Into The Sharing Economy, FoRTUNE (June 17, 2015), available at http://fortune.com/2015/06/17/uber-drivers-are-employees-sharing-economy/. (attributing the per-hour gender earnings gap to three factors: men having more experience; men driving in more lucrative locations (driven largely by where drivers live and, to a lesser extent, safety), and men driving faster).

2 Laura W. Murphy, Airbnb's Work to Fight Discrimination and Build Inclusion: A Report Submitted to Airbnb, at 27, BLOG.ATAIRBNB (Sept. 8, 2016), available at

http://blog.atairbnb.com/wp-content/uploads/2016/09/REPORT_Airbnbs-Work-to-FightDiscrimination-and-Build-Inclusion.pdf. ("[T]he Airbnb community can promote empathy and understanding across all cultures.”).

*Corresponding author: Naomi Schoenbaum, Associate Professor of Law, George Washington University School of Law, Washington, DC 20052, USA, E-mail: nschoenbaum@law.gwu.edu 
voluntarily adopted measures to combat charges of discrimination. ${ }^{3}$ This Article looks at these efforts, and considers their intersection with antidiscrimination law, highlighting both how law can play a critical role in spurring antidiscrimination efforts by firms that it does not regulate, but also how antidiscrimination law might nonetheless be undermined by these efforts.

Scholars have debated how much the regulatory force of law as compared with the non-legal force of norms shapes behavior. The response of sharing-economy firms to concerns of discrimination provides a fruitful opportunity to explore this question in a context where we might think norms are operating particularly powerfully, and also where we might think that law has played a critical role in shaping these norms, and finally where we might be concerned to leave the regulation of such a fundamental interest-equality - to forces outside of law.

Scholars' focus on whether antidiscrimination law applies to the sharing economy ${ }^{4}$ overlooks the way that norms can shape behavior, even without direct legal regulation. The strong response of firms to concerns of discrimination shows us just how far we have come in terms of the expectation of nondiscrimination in the provision of what have come to be seen as critical services, including ride-sharing and home-sharing. Indeed, in some respects, antidiscrimination norms in the sharing economy appear to be ahead of law. For example, sharing-economy firms have taken measures to address discrimination by individual riders against drivers or by individual hosts against guests-discrimination that law typically wouldn't regulate in the traditional economy. However, the market response also reveals other respects in which norms of equality may lag behind laws of equality in ways that are troubling, for example, in permitting and even encouraging sex discrimination in intimate spaces to address safety concerns. The market response to discrimination may also fail to accord with the goals of antidiscrimination law and may even be intended to quell public pressure for a regulatory response at all. So while market forces may regulate more efficiently than law, we might be concerned about relying on these norms to guarantee equality.

This Article proceeds in three parts. First, this Article catalogues the concerns of discrimination raised in the sharing economy and firms' voluntary

3 See infra Part I.B.

4 See, e.g. Nancy Leong \& Aaron Belzer, The New Public Accommmodations: Race Discrimination in the Platform Economy, 105 GEO. L. J. 1271 (2017) (focusing on how public accommodations law applies to race discrimination in the sharing economy); Brishen Rogers, The Social Costs of Uber, 82 U. CHI. L. REV. DiAlogue 85, 95-97 (2015), available at https://lawreview.uchicago.edu/sites/ lawreview.uchicago.edu/files/uploads/Dialogue/. Rogers_Dialogue.pdf (focusing on how antidiscrimination law applies to Uber). 
responses to these concerns. By voluntary, I mean responses that were not mandated by the force of law, although I take up later how law has played a role in shaping these responses. The focus here is on two sectors of the sharing economy-ride-sharing and home-sharing-and two bases of discriminationrace discrimination and sex discrimination-in the United States. ${ }^{5}$

Second, this Article looks at how law plays a role in shaping firms' responses to discrimination, even when firms claim not to be regulated by antidiscrimination law. If sharing-economy firms operate in an ambiguous regulatory space, they will have some incentive to implement antidiscrimination practices. So I first briefly address whether antidiscrimination law does in fact cover the type of discrimination that firms have responded to, and express skepticism about this. I then introduce law and norms scholarship to consider the respective roles of law and norms-and their interaction-in the sharing-economy's efforts to combat discrimination. Antidiscrimination law appears to have shaped norms and expectations of nondiscrimination at work and in public accommodations such that the public finds rampant discrimination in the sharing economy unacceptable, regardless of whether antidiscrimination law regulates these transactions. I explore some of the mechanisms by which law is influencing norms here, as well as some of the ways that these norms diverge from law.

Third, I consider some of the consequences of addressing discrimination through norms. Relying on the force of norms rather than the force of law brings the benefit of lower enforcement costs, with arguably fewer incursions on autonomy. However, relying on norms rather than law also raises concerns, as this allows firms more leeway to pick and choose their responses. Equality is an area where we typically want forward progress, and the market is more likely to be (though not always) responding to current antidiscrimination norms, rather than pushing them forward. Firms might also look for the cheapest means to avoid discrimination, without considering how the mechanisms they rely on fail to comport with the goals of antidiscrimination law. Here, the

5 This phenomenon certainly stretches worldwide, see, e.g. Int'l Finance Corp., World Bank Group, Driving Toward Equality: Women, Ride-Hailing, and the Sharing Economy (2018), available at https://www.ifc.org/wps/wcm/connect/ec101088-8a12-4994-9918. 14455b8e2cd9/ 00418 + IFC + DTE + Report_Complete_Layout + Final2-pxp.pdf?MOD = AJPERES; and to other sectors of the peer-to-peer economy; see Ian Ayres, Mahzarin R. Banaji, \& Christine Jolls, Race Effects on Ebay, 46 RAND J. ECONOMICS 891 (2015) (documenting race discrimination against sellers of baseball cards on Ebay by varying race of person holding the card), and other forms of discrimination; Lynne Soraya, Disability and the Sharing Economy, PsYchol. TODAY (Aug. 11, 2014), available at https://www.psychologytoday.com/blog/aspergers-diary/ 201408/disability-and-the-sharing-economy. I narrow the focus here to make the analysis tractable. 
biggest implication might be that by quelling public pressure for legal responses to discrimination, firms' antidiscrimination efforts reduce the likelihood that they will be governed by antidiscrimination law at all. Although much could be said about the respective role that law and norms should play in regulating discrimination in the sharing economy, this brief Article does not take on this prescriptive task. Rather, it describes the intersecting ways that law and norms are already shaping discrimination and antidiscrimination in the sharing economy, highlighting a range of consequences, with an aim toward building a foundation for future work.

\section{Discrimination and Antidiscrimination in the Sharing Economy}

Sharing-economy firms have strenuously objected to coverage by antidiscrimination law, claiming that they are not the types of entities covered by these laws. ${ }^{6}$ At the same time, however, they have taken a variety of actions in response to concerns of discrimination in the provision of their services. Before the next two Parts seek to contextualize these responses and discuss their implications, this Part catalogues some of the concerns of discrimination that have been raised in the sharing economy and presents a typology of the kinds of responses sharing-economy firms have taken to address these discrimination concerns.

\section{A Discrimination}

Concerns about discrimination in ride-sharing and home-sharing were not surprising based on the relationship between intimacy and discrimination ${ }^{7}$ and the tendency of sharing-economy firms to personalize the transactions, predicating the transaction on the relationship between users rather than with the firm. ${ }^{8}$ Due in large part to the lack of trust in these new firms and these new transactions (e.g. riding in a stranger's car or staying in a stranger's home), sharing-economy firms allowed themselves to recede into the background, and instead

6 See sources cited supra note 1.

7 See Naomi Schoenbaum, The Law of Intimate Work, 90 WASH. L. REV. 1167, 1187-90 (2015).

8 See Naomi Schoenbaum, Gender and the Sharing Economy, 43 Fordham Urb. L.J. 1023, 1033-35 (2016). 
emphasized the connection between the worker and the customer, whether it be driver and rider or host and guest. ${ }^{9}$ Firms highlighted the personal characteristics of users-including names, photographs, and ratings-to build trust in these transactions. ${ }^{10}$

It did not take long before formal and informal charges of discriminationand the research to back it up-started filing in. ${ }^{11}$ In the home-sharing space, lawsuits were brought against Airbnb for facilitating racial discrimination by hosts against black guests, who claimed that they were rejected from bookings because of their race. ${ }^{12}$ Research confirmed this tendency. One study found that lodging requests by those with black-sounding names were sixteen percent less likely to be accepted than those with white-sounding names. ${ }^{13}$

Similar concerns of discrimination by workers against customers have been raised in the ride-sharing context. One study of Uber and Lyft found that riders with African-American-sounding names waited thirty-five percent longer for rides and were, in some areas, up to three times as likely to have their ride canceled compared to their white counterparts. ${ }^{14}$ Concerns about the impact of race on outcomes for ride-share drivers have also been raised. Uber has been sued for

9 See id.

10 See id. Scholars have long raised concerns about the ability to discriminate on the basis of this information. See Ayres, Banaji, \& Jolls, supra note 5, at 891 (documenting race discrimination against sellers of baseball cards on Ebay by varying race of person holding the card); Marianne Bertrand \& Sendhil Mullainathan, Are Emily and Greg More Employable than Lakisha and Jamal? A Field Experiment on Labor Market Discrimination, 94 AM. ECON. REv. 991, 991-92 (2004).

11 See, e.g. Katie Benner, Airbnb Adopts Rules to Fight Discrimination By Its Hosts, N.Y. TIMES (Sept. 8, 2016), available at https://www.nytimes.com/2016/09/09/technology/airbnb-anti-dis crimination-rules.html. ("For much of this year, Airbnb has been under fire over the ease with which its hosts can reject potential renters based on race, age, gender or other factors. The barrage of criticism began with a Harvard University study, snowballed with firsthand accounts of discrimination from Airbnb guests and has prompted a lawsuit.").

12 See Vauhini Vara, How Airbnb Makes It Hard to Sue for Discrimination, NEW YoRKER (Nov. 3, 2016), available at https://www.newyorker.com/business/currency/how-airbnb-makes-it-hardto-sue-for-discrimination; Katie Benner, Federal Judge Blocks Racial Discrimination Suit Against Airbnb, N.Y. Times (Nov. 1, 2016), available at https://www.nytimes.com/2016/11/02/technol ogy/federal-judge-blocks-racial-discrimination-suit-against-airbnb.html.

13 See Benjamin G. Edelman \& Michael Luca, Digital Discrimination: The Case of Airbnb.com, 9 AM. ECON. J.: APP. ECON. 1 (2017), available at http://pubs.aeaweb.org/doi/pdfplus/10.1257/app. 20160213.

14 Yanbo Ge et al., Racial and Gender Discrimination in Transportation Network Companies, at 2, NBER Working Paper No. 22,776 (Oct. 2016), available at http://www.nber.org/papers/w22776. 
race discrimination in its rating system. ${ }^{15}$ The suit alleges that Uber's system for rating drivers from one to five stars is racially discriminatory, as it allows drivers' fate on the platform to turn on potentially discriminatory assessments by riders. $^{16}$

Concerns of sex discrimination have also been raised in the sharing economy. The same study finding race discrimination against Uber and Lyft riders also found that female riders were subjected to longer rides than male riders, which produced not only a more expensive ride for women, but also the opportunity for the driver to "flirt[] to a captive audience."17 Claims of sexual harassment and sexual assault of both female drivers and female riders have also been raised. ${ }^{18}$ Similar concerns of sexual assault have plagued the homesharing sector. ${ }^{19}$ While sexual harassment in the sharing economy has not generally been recognized as sex discrimination as it has in the traditional economy, at least when experienced by workers, it has been recognized as an issue of women's safety. ${ }^{20}$ At least one lawsuit has been filed focusing on the safety concerns of ride-sharing for women. ${ }^{21}$

15 The plaintiff is a former Uber driver who was deactivated based on low passenger ratings, which he claims are because he is Asian. See Hannah Levintova, Uber Just Got Hit with Another Legal Fight, MotHER Jones (Oct. 7, 2016, 7:46 PM) available at http://www.motherjones.com/ media/2016/10/uber-racial-bias-lawsuit-liss-riordan/.

16 The double bind for Uber may be its recent justification for not adding a tipping function to its app because riders have racial biases, which would infect tipping and result in discriminatory pay for drivers. See id. ("Which raises the question ... if you know your customers discriminate, then how can you have a system for determining who is going to be fired that relies completely on customer rating?").

17 Ge et al., supra note 14 , at 2.

18 These claims range from what we might consider inappropriate flirting and come-ons to criminal activity as serious as kidnapping and rape. See Schoenbaum, supra note 8, at 1044-45; Lauren Gambino, Uber Faces Lawsuit in US over Two Alleged Sexual Assaults by Drivers, THE GUARDIAN (Oct. 8, 2015, 7:20 PM), available at https://www.theguardian.com/technology/2015/ oct/08/uber-lawsuit-alleged-sexual-assaults-boston-south-carolina.

19 Shivani Vora, Airbnb Sued by Guest Who Says a Host Sexually Assaulted Her, N.Y. TIMES (Aug. 2, 2017), available at https://www.nytimes.com/2017/08/02/travel/airbnb-lawsuit-hostsexual-assault.html.

20 HyreCar, How Safe Is Uber and Lyft for Female Drivers? HyreCar Blog (Sept. 5, 2017), available at http://hyrecar.com/blog/uber-lyft-female-drivers-safety/; see Stacy Perman, Is Uber Dangerous for Women? MARIE ClAIRE (May 20, 2015), available at http://www.marieclaire.com/ culture/news/a14480/uber-rides-dangerous-for-women.

21 See Gambino, supra note 18 ("What Uber does not share with riders is that making the choice to hail a ride after drinking also puts them in peril from the Uber drivers themselves. ... By marketing heavily toward young women who have been drinking while claiming that rider safety is its \#1 priority, Uber is instead putting these women at risk.”). 
In addition, concerns of occupational sex segregation and a gender pay gap have been raised in the ride-sharing context. Women make up a small percentage of the ride-sharing workforce-just $14 \%$ of Uber drivers and $20 \%$ of Lyft drivers. ${ }^{22}$ And women who do go into ride-sharing earn on average $34 \%$ less per month than their male counterparts, though much of that is due to the fact that women are more likely to drive part-time. These gendered aspects of ridesharing are reflective of the safety concerns discussed above and several other factors, including men's greater experience on the platform, as well as the fact that they drive faster. ${ }^{23,24}$

\section{B Antidiscrimination}

This Section considers the sharing economy's response to the concerns of discrimination raised in the last Section. While claiming not to be regulated by antidiscrimination law, these firms nonetheless have taken a variety of actions to combat and remedy discrimination. This Section provides an analytical typology of the different types of seemingly non-legal moves firms have made in response to discrimination.

\section{Nondiscrimination Policies}

The major home-sharing and ride-sharing firms have nondiscrimination policies. Last year Airbnb released a report detailing its antidiscrimination initiatives taken in response to findings of discrimination on the platform and lawsuits alleging race discrimination. Airbnb hired prominent advisers, including former United States Attorney General Eric H. Holder Jr., to help formulate anti-bias policies. ${ }^{25}$ One of these new policies was a requirement that all of Airbnb's users (hosts and guests) agree to its "community commitment": "We believe that no

22 Patrick Sisson, Safr, a Female-Friendly Uber Alternative, Launches with Mission to Empower Women, CuRBED (Apr. 5, 2017, 5:02 PM), available at https://www.curbed.com/platform/amp/ 2017/4/5/15195806/uber-safr-ridehailing-for-women.

23 See Schoenbaum, supra note 8, at 1049 (discussing safety and other concerns that lower the income of women drivers and discourage them from serving as ride-sharing drivers at all, including the fact that the most lucrative driving times-weekend nights-are those that present the most safety risks due to drunken passengers); Sisson, supra note 22 ("[S]afety concerns, which keep female drivers from working the more lucrative late-night shifts, are a big reason for the pay discrepancy.”). 24 See Cook, et al., supra note 1.

25 See Benner, supra note 11. 
matter who you are, where you are from, or where you travel, you should be able to belong in the Airbnb community. By joining this community, you commit to treat all fellow members of this community, regardless of race, religion, national origin, disability, sex, gender identity, sexual orientation or age, with respect, and without judgment or bias."26

Airbnb also has a more specific nondiscrimination policy. With regard to race (as well as color, ethnicity, national origin, religion, sexual orientation, gender identity, or marital status), Airbnb hosts may not decline a guest, otherwise impose any different terms and conditions, or post any listing or otherwise make any statement that discourages or indicates a preference for or against any guest on this basis. ${ }^{27}$ With regard to sex, Airbnb imposes the same policy, except when the host shares living space (e.g. bathroom, kitchen, or common areas) with the guest. ${ }^{28}$ In those circumstances, the host may choose to make a unit available only to guests of the host's gender. ${ }^{29}$

Ride-sharing firms too have implemented nondiscrimination policies. Uber's community commitment states that "when you use Uber you will meet people who may look different or think differently from you. Please respect those differences. We want everyone to feel welcome when they use Uber." ${ }^{30}$ Uber specifically prohibits discrimination by drivers and riders, including refusing to provide or accept services, based on race and sex (among other grounds). ${ }^{31}$ And Uber has policies to combat sexual harassment and assault such as barring users touching or flirting with other users, commenting on someone's appearance, and asking whether they are single, as well as a blanket no-sex rule between drivers and riders. ${ }^{32}$

In addition to these substantive antidiscrimination policies, Airbnb "overhauled its enforcement protocols" as part of its 2016 antidiscrimination response, including adding new tools to route discrimination concerns to trained specialists. " 33 "If a guest or a host believes they have been discriminated against, Airbnb will investigate their complaint and take action if the policy has been

26 Murphy, supra note 2, at 19.

27 Id. at 29.

28 Id. at 29-30.

29 Id.

30 Uber, Uber Community Guidelines, UBER (last visited Mar. 7, 2018), available at https://www.uber.com/legal/community-guidelines/us-en/.

31 Uber, Uber Non-Discrimination Policy, UBER (last visited Mar. 7, 2018), available at https://www.uber.com/legal/policies/non-discrimination-policy/en/.

32 Uber, supra note 31.

33 See Murphy, supra note 2, at 11, 20. 
violated."34 Among other enhanced enforcement policies, every guest who is denied a reservation will receive information about Airbnb's community standards and how to report instances of discrimination. ${ }^{35}$

Despite the addition of more robust reporting and investigation mechanisms, the penalties for violating Airbnb's nondiscrimination policy are still not clear. ${ }^{36}$ Airbnb did add a remedy for discrimination, so that if a guest is not able to book a listing because she has been discriminated against, Airbnb will ensure the guest finds a place to stay. ${ }^{37}$ However, Airbnb does not explain the consequences for the discriminating hosts. While the enforcement mechanisms in the ride-sharing context are less clear, ${ }^{38}$ the penalties are clearier. Uber's policy states that any rider or driver found to have violated its nondiscrimination policy will lose access to Uber. ${ }^{39}$

\section{New Personnel and Training}

Sharing-economy firms have also responded to concerns of discrimination with personnel changes. Airbnb, for example, has hired a permanent, full-time product team to fight bias and promote diversity. ${ }^{40}$ And while Airbnb does not consider its hosts to be employees, it is offering them training to help them learn how to fight bias, and will highlight hosts that have undergone this training. ${ }^{41}$ Airbnb has also committed to becoming a more diverse company at the corporate level by implementing what it calls a "diversity rule," which mandates that

$34 \mathrm{Id}$. at 20.

35 See id. at 21.

36 In one instance from 2014, before the introduction of the new policy, AirBnB removed a listing that banned gay couples. Nick Duffy, Accommodation Website Airbnb Removes Listing That Banned Gay Couples, PINKNEws (Nov 23, 2014), available at http://www.pinknews.co.uk/ 2014/11/23/accomodation-website-airbnb-removes-listing-that-banned-gay-couples/.

37 See Murphy, supra note 2, at 21.

38 See Letter from Al Franken, U.S. Senator, to Travis Kalanick, Chief Executive Officer of Uber Technologies, Inc., and Logan Green, Chief Executive Officer of Lyft, Inc. (Nov 2, 2016), available at https://www.franken.senate.gov/files/letter/161102_UberLyft.pdf. [hereinafter Franken Letter] (asking Uber and Lyft whether they audit rider or driver cancellations for discrimination).

39 See Uber, supra note 31. Note the concern that Uber itself may exercise this power in ways that concern us, using concerns of discrimination as an excuse to force out drivers who are agitating for more rights, for example. I thank my commentator Shelly Kreiczer Levy for this observation.

40 See Murphy, supra note 2, at 24.

41 See id. at 22. 
all candidate pools for senior-level positions include women and candidates from underrepresented backgrounds. ${ }^{42}$

\section{Depersonalization Mechanisms}

As referenced above, sharing-economy firms personalized their transactions between users, focusing on personal profiles and ratings, to build trust in these newfangled transactions. ${ }^{43}$ As trust in these firms and their transactions grew, reducing the need for personalization, so did concerns of discrimination, pressing firms to reduce personalization. ${ }^{44}$ Firms responded to these twin forces-the reduced need for trust and the increased concern about discrimination-by depersonalizing and sometimes even anonymizing their transactions. ${ }^{45}$ Airbnb, for example, has expanded its instant booking program that allows users to make a reservation without host approval. ${ }^{46}$ This takes away the personal selection aspect of the transaction to reduce discrimination that can arise from discretion. In addition, when a host rejects a reservation request based on unavailability of the requested dates, Airbnb will again remove the host's discretion, automatically blocking the calendar for subsequent reservation requests for those dates. ${ }^{47}$ This reduces the host's ability to rely on unavailability as a cover for race discrimination.

Some have suggested that Airbnb take additional moves toward depersonalization to target discrimination, including removing photographs from its guest profiles and allowing guests not to use their real names. ${ }^{48}$ But Airbnb would not remove host or guest photos from its site because "photos are an important feature that help build relationships and allow host and guests to get to know one another before a booking begins," which is "far different than merely facilitating an

42 See id. at 24. Uber has also relied on more diverse hiring to address concerns of discrimination at the corporate level. See Eric Newcomer, Uber Adds Two Women to Top Ranks Amid Work Culture Scrutiny, BLOOMBERG NEws (June 6, 2017, 5:14 PM), available at https://www.bloom berg.com/news/articles/2017-06-06/apple-executive-bozoma-saint-john-said-to-be-joining-uber. 43 See supra notes 8-10 and accompanying text.

44 See Naomi Schoenbaum, Intimacy and Equality in the Sharing Economy, in THE CAMBRIDGE HANDBOOK OF THE LAW OF THE SHARING ECONOMY 459 (Nestor Davidson, John Infranca, \& Michele Finck eds., 2019).

45 See id. at 463-66.

46 Murphy, supra note 2, at 22.

47 See id. at 20.

48 See, e.g. Jun Li et al., A Better Way to Fight Discrimination in the Sharing Economy, HaRv. Bus. REv. (Feb. 27, 2017), available at https://hbr.org/2017/02/a-better-way-to-fight-discrimina tion-in-the-sharing-economy. 
anonymous transaction." 49 Instead, the firm would take more modest steps towards depersonalization, such as "experiment[ing] with reducing the prominence of guest photos in the booking process" and "better featur[ing] objective information" and "reputation-enhancing data such as reviews and verified ID."50

New sharing-economy firms have popped up to fill the void that Airbnb has seemed to create in the home-sharing space. These firms specifically aim to combat discrimination through "blind" platforms. Innclusive, a peer-to-peer lodging site, has been developed as a more inclusive alternative to Airbnb. It is specifically designed to "remove the possibility of bias." Until hosts agree to a booking, they cannot see a guest's profile photo or personal information. Instead, they see only their ratings.

Ride-sharing services have also relied on depersonalization to fight discrimination. Uber and Lyft match riders and drivers based on proximity, so they cannot choose each other based on race-at least initially. ${ }^{51}$ But there are other opportunities for both riders and drivers to discriminate. As for riders, once the rider is matched with a driver, the rider will see the driver's "name, license plate number, photo, and rating-so you know who's picking you up ahead of time."52 This allows the rider to cancel the ride based on race or sex of the driver, but at a cost, after having been matched with the driver, and having to wait for another more distant driver.

As for drivers, Uber, the largest and most popular ride-sharing service, only allows drivers to see a prospective rider's name and photo after accepting a ride request. ${ }^{53}$ And Uber's deactivation policy allows the company to ban drivers who cancel too many rides, which may help to reduce the chance that drivers

49 Murphy, supra note 2, at 23.

50 Id. (citing research that "reputation systems like review scores can significantly extend the trust between dissimilar users," and thus that "[m]aking review and other objective data more readily available could help overcome some people's inclination to only trust people who are like them"); Ray Fisman \& Michael Luca, Fixing Discrimination in Online Marketplaces, HARV. Bus. REV. (Dec. 2016), available at https://hbr.org/2016/12/fixing-discrimination-in-online-mar ketplaces. (explaining that HomeAway shows photos only of the property for rent and withholds photos until a later page or doesn't show them at all).

51 Uber, Trip Safety: Our Commitment to Riders, UbER (last visited Mar. 7, 2018) available at https://www.uber.com/ride/safety/. ("All ride requests are blindly matched with the closest available driver.")

52 Id.

53 See Fisman \& Luca, supra note 50; Ge et al., supra note 14, at 2. Other ride-sharing services retain a more personal character. See Schoenbaum, supra note 8, at 1035 (discussing ways in which Lyft offers a more personal service than Uber). Lyft drivers see both the name and photo of the rider prior to accepting or denying a ride. In theory, this should make it easier for Lyft drivers to discriminate against riders. But it appears that Uber drivers are accomplishing the 
will cancel once they know a rider's identity. It is not clear whether either Uber or Lyft audit driver cancellations for discrimination. ${ }^{54}$

\section{Safety Features}

Sharing-economy firms have implemented features to respond to safety concerns generally, which could play a role in addressing concerns of harassment and assault against women users. ${ }^{55}$ Uber, for example, lists among its safety features that it automatically finds the rider's location and provides door-todoor service; provides the rider and driver with information about each other (name, license plate, photo, and rating) after they are matched to make sure they are connecting with the right person; allows riders and drivers to share information about the trip with friends and family so that they can follow the route and know when to expect a rider; logs GPS data to keep a record of each trip; provides round-the-clock support if any concerns arise; and assists law enforcement with investigations. ${ }^{56}$

A new ride-sharing firm in Boston, Safr, offers additional safety features "with the needs of women in mind." 57 Safr provides a range of mechanisms intended to promote safety beyond the likes of Uber and Lyft, including vetting each driver with an in-person interview and driving session; conducting the

same discrimination-just by cancelling after the ride has been accepted. See Ge et al., supra note 14 , at 2 .

54 See Franken Letter, supra note 38 (asking Uber and Lyft whether they engage in such measures).

55 Safety concerns can of course affect users of any sex. Even treating these safety features as antidiscrimination measures may reinforce stereotypical notions of women as weak and in need of defense. However, just like sexual harassment in the traditional economy, sexual harassment and assault in the sharing economy can be an issue of sex equality not only because it disproportionately affects women, but because it can be carried out in ways that reinforce traditional gender norms. For a discussion of sexual harassment as a tool of gender norm enforcement, see generally Katherine Franke, What's Wrong with Sexual Harassment? 49 STAN. L. REV. 691 (1997), and Vicki Schultz, Reconceptualizing Sexual Harassment, 107 YALE L.J. 1683 (1998).

56 Uber, supra note 51; Uber, Safety and Confidence Behind the Wheel: Our Commitment to Drivers, UBER (last visited Mar. 7, 2018), available at https://www.uber.com/drive/safety/. Some of Uber's safety claims and a safety fee it charged for conducting background checks on drivers have been challenged in a lawsuit. See Biz Carson, Uber Generated Almost $\$ 500$ Million From "Safe Rides" Fees, BUSINESS INSIDER (Aug. 31, 2016, 8:43 PM), available at http://www.busi nessinsider.com/uber-449-million-safe-rides-fees-2016-8.

57 Safr, Safr Is a Mission-Driven Ridesharing Company Built with the Needs of Women in Mind, SAFR (last visited Mar. 7, 2018), available at https://www.gosafr.com/about-safr/. 
"most comprehensive background checks available" of drivers' criminal and motor vehicle history; offering drivers a bystander awareness and ride-safety training session; paying drivers more than the industry standard so they are incentivized to provide better service; providing round-the-clock real-time monitoring of rides and an "SOS" button that either rider or driver can hit if they are uncomfortable with their ride; and assigning a color to drivers and riders that must be verified to ensure the driver picks up the correct rider. ${ }^{58}$

\section{Identity-Based Responses}

One response to concerns of sexual harassment and assault of women has been to meet discrimination with discrimination. Lyft began as a ride-sharing service for women only. ${ }^{59}$ Years later, Safr was developed as a women-only ride-sharing service, ${ }^{60}$ but decided to include men too out of concern of legal liability. ${ }^{61}$

58 See id.

59 See Ellen Huet, Why Aren't There More Female Uber and Lyft Drivers? FoRBES (Apr. 9, 2015), available at http://www.forbes.com/sites/ellenhuet/2015/04/09/female-uber-lyftdrivers.

60 See Jaclyn Reiss, New Ride-Hailing Service Coming to Boston Caters Only to Women, Boston GLOBE (Mar. 25, 2016), available at https://www.bostonglobe.com/business/2016/03/24/new-massstartup-like-uber-lyft-but-for-women/1LmxftfcQDvl5GihRu9YNM/story.html. (explaining that "[t] his service is tailored so passengers can enjoy their commutes testosterone free, with drivers who are less likely to hit on them and have undergone a thorough vetting process," and also that "[d] rivers of this service will not need to perfect a stern but non-confrontational 'don't fuck with me' tone when passengers reach to touch their wrist”). More troublingly, the founder of Safr also cites the film Pretty Woman and the relationship between the businessman and the down-on-her-luck hooker as formative of his protective disposition to members of the opposite sex. Id.

Sex-matching may also allow for enhanced intimacy. See Schoenbaum, supra note 8, at 1041-42; Susan Zalkind, Confessions of a Female Uber Driver: Women-Only Rideshare Has Many Pluses, THE GUARDIAN (Apr. 21, 2016, 8:00 AM), available at https://www.theguardian.com/ technology/2016/apr/21/chariot-for-women-female-only-rideshare-uber. (noting that "the most satisfying part about this set up: the potential for great conversation. Driving people from place to place, the backseat of a taxi, or rideshare car, often seamlessly turns into a confessional booth. The conversations I had with women were always refreshingly frank. Sometimes the subject matter veered into more serious territories, like loneliness, in vitro fertilization and sexual assault. ... I became adept at reviewing the pros and cons of online dates. I pondered with my passenger as I pulled her up to meet a prospective suitor only to find he was wearing a particularly bold pair of velour pants. For my own part, I entertain my female riders with tales of less peaceful commutes, like my misadventures with the men's lacrosse team).

61 Curt Woodward, Can "Uber for Women" App Really Refuse Service to Men? It Might Soon Find Out., Boston GLOBE (Jan. 26, 2017), available at https://www.bostonglobe.com/business/2017/01/ 26/uber-for-women-app-close-launch-boston-amid-legal-questions/sy1pBJoTCCsW3husELGVeI/ 
Although completely sex-segregated services have ultimately been dropped, what has remained in some sharing-economy firms is the ability to choose one's transacting partner on the basis of sex. ${ }^{62}$ Sidecar, a one-time competitor to Uber and Lyft, offered this option, ${ }^{63}$ and Safr now does. ${ }^{64}$ Safr sells this feature as a corrective to occupational segregation and the pay gap in the ride-sharing industry. ${ }^{65}$ Currently, all of Safr's drivers are women. ${ }^{66}$

Even the biggest sharing-economy firms allow for some overt reliance on sex. As referenced above, Airbnb users may discriminate on the basis of sex when living spaces are shared. ${ }^{67}$ And Uber has suggested that focusing on the sex of its drivers can remedy safety concerns. In the wake of such concerns, Uber pledged to hire one million women drivers. ${ }^{68}$

story.html; Curt Woodward, Uber, But for Women? Probably Illegal, Experts Say, Boston GLOBE (Mar. 28, 2016), available at https://www.bostonglobe.com/business/2016/03/28/uber-but-forwomen-probably-illegal-experts-say/QP5fYbQfvXUnKcEs0BqhEP/story.html.

62 See Hiawatha Bray, Hitchhiking Goes Digital with Tripda Ride Sharing Service, Boston GLOBE (Nov. 21, 2014), available at https://www.bostonglobe.com/business/2014/11/21/hitchhikinggoes-digital-withtripdaride-sharing-service/4JjciQxKybC2FD7HymwxUK/story.html.

63 See Johana Bhuiyan, Men Are Using Uber's Lost-and-Found Feature to Harass Female Drivers, BuZz FEED (Feb. 10, 2015), available at http://www.buzzfeed.com/johanabhuiyan/faced-withharassment-female-uber-drivers-often-left-to-fend\#.ojJ9JMAq3. (introduced this option, many of their female drivers reported an increase in ride requests from female passengers); Kaleigh Rogers, Why Doesn't Uber Let Women Passengers Choose Women Drivers, MotHERBOARD (Apr. 6, 2015), available at http://motherboard.vice.com/read/why-doesnt-uber-let-women-passengerschoose-women-drivers. One now-defunct long-distance ride-sharing service, Tripda, also allowed drivers to choose only female passengers. See Bray, supra note 62.

64 available at https://www.gosafr.com/riders/. ("We give you the power to choose the gender of your driver. Man or woman, we'll get you where you need to go safely.”).

65 See Sisson, supra note 22 (explaining that "gender preference option for drivers will get more women in the driver's seat and help them make more money"). Other Safr features are also intended to serve this function as well. See id.; supra notes 57-58 and accompanying text (listing safety features offered by Safr).

66 See id.

67 See supra notes $28-29$ and accompanying text.

68 See Uber, Meet the Uber Team Driving Our Women Partner Program, UbER (July 27, 2015), available at http://newsroom.uber.com/2015/07/meet-the-uber-team-driving-our-women-part ner-program/. (one million women drivers globally by 2020); Jessica Goldstein, You Shouldn't Have to Hire A Female Driver: Uber's Hiring Pledge Isn't Enough, THINKPROGRESS (Mar. 12, 2015), available at http://thinkprogress.org/culture/2015/03/12/3633002/shouldnt-female-driver-ubershiring-pledge-isnt-enough/. 


\section{The Force of Law in the Antidiscrimination Response}

This Part addresses the role of law in the seemingly non-legal antidiscrimination responses by sharing-economy firms. It first evaluates whether antidiscrimination law does regulate the type of discrimination that firms have responded to, and expresses skepticism about this, laying the groundwork for the role of norms here. Next, it highlights some of the most notable facets of the antidiscrimination norms that appear to be at work in the sharing economy, contextualizing them within the law and norms literature. Finally, the Part considers the interaction between law and norms here, considering the ways in which law-even when it is not regulating-plays a critical role in shaping norms of nondiscrimination in the sharing economy.

\section{A Law's Regulatory Force}

There is reason to believe that current antidiscrimination law, including public accommodations law (Title II of the Civil Rights Act of 1964), fair housing law (the Fair Housing Act (FHA), and Title VIII of the Civil Rights Act of 1968), and employment discrimination law (Title VII of the Civil Rights Act of 1964), does not cover sharing-economy transactions. These laws generally do not cover discrimination by individual suppliers of services or by individual customers, and thus they are unlikely to apply to individual sharing-economy users themselves (hosts, guests, drivers, and riders), except to the extent that home-sharing hosts are acting more like hotels in that they are renting out multiple dwellings that are not owner-occupied. ${ }^{69}$

As for the firms themselves, the main focus of coverage here, they have so far largely successfully claimed that they are not the types of entities covered by these laws, in that they are not hotels covered by public accommodations law or brokers covered by fair housing law or employers covered by fair employment laws. ${ }^{70}$ Rather, they are simply networks or platforms that provide

69 See, e.g. 42 U.S.C. $\S 2000$ e(b) (defining a covered "employer" as one with "fifteen or more employees"); James D. Walsh, Reaching Mrs. Murphy: A Call for Repeal of the Mrs. Murphy Exemption to the Fair Housing Act, 34 HARV. C.R.-C.L. L. REV. 605, 605 (1999) (describing socalled Ms Murphy exception to the FHA, which exempts from coverage a dwelling has four or fewer rental units with the owner living in one of those units).

70 One federal court has rejected Uber's claim on summary judgment that it is not an employer, O’Connor v. Uber Techs., Inc., 82 F. Supp. 3d 1133 (N.D. Cal. 2015), but this ruling is on appeal, 
the means for people to connect in the exchange of these services. Even to the extent that antidiscrimination law covers sharing-economy firms, many of these laws contain exceptions for discrimination in intimate settings, and these exceptions might apply in the more intimate settings of sharing-economy transactions. ${ }^{71}$

\section{B Norms}

This Section considers the role of norms in the sharing-economy's antidiscrimination responses. ${ }^{72}$ Before proceeding forward, two clarifications are in order. First, the focus here is on norms related to discrimination, but there are surely other non-legal forces at play behind some of the firms' actions described in Part I.B. ${ }^{73}$ Second, by focusing on norms, I do not mean to ignore the role of law in generating norms. Rather, I mean to explore how norms (and the attitudes and

and drivers must contend not only with this issue but also with questions about the appropriateness of class action certification and even litigation in light of arbitration agreements the drivers signed. Regardless of the merits of their legal position, sharing-economy firms have gained a leg up in advocating for it because of legal silos and first-mover advantages, as described by Professor Diane Ring in this volume. See Diane Ring, Silos and First Movers in the Sharing Economy Debates, 13 L. \& ETHICs Hum. RTS. 61 (2019).

71 See Schoenbaum, supra note 8, at 1064-65 (describing bona fide occupational qualification under Title VII and the Mrs. Murphy exception under the FHA).

72 There is some overlap with corporate social responsibility, although that concept tends to refer to corporate behavior for societal rather than shareholder benefit, regardless of whether it is regulated by law. See David L. Engel, An Approach to Corporate Social Responsibility, 32 STAN. L. REV. 1, 5-6 (1979) (defining the term "to denote the obligations and inclinations, if any, of corporations organized for profit, voluntarily to pursue social ends that conflict with the presumptive shareholder desire to maximize profit").

73 Some changes may have been prompted by consumer demand. Airbnb believes that travelers accustomed to hotels have come to expect that they can have hosts who act like hotel staff members, who blend into the background or who won't be there at all. Note that market forces and concerns about discrimination may be linked. For example, Airbnb's expansion depends partly on whether people of different nationalities and ethnicities feel welcome to the platform. And making sure that the firm is open to all can be a boon to business simply as a matter of reputation.

As for depersonalization, once the sharing economy matured to a point where sufficient trust had been built in the transactions themselves as well as the firms that offered them, firms might have decided that the business costs of personalization were not worth it. As in the traditional economy, relying too much on relationships between consumers and workers risks the relationship between the consumer and the firm. See Schoenbaum, supra note 7, at 1212-13. A firm like Uber ultimately wants riders to keep coming back to Uber rather than to any particular driver on the platform. 
preferences that underlie them) are playing a role here. The complex interaction between how law shapes norms, attitudes, and preferences will be taken up in the next Section.

As an initial matter, it is worth saying a few words about what the literature means when it refers to norms, and the two different types of norms that are operating here. When referring to norms, the literature refers to "informal social regularities that individuals feel obligated to follow because of an internalized sense of duty, because of a fear of external non-legal sanctions, or both."74 There are two ways in which antidiscrimination norms may be operating in the context of the sharing economy, and it is important to make these two different mechanisms apparent. Norms "may be created and enforced in a centralized or decentralized manner."75 To illustrate this distinction, Professor Richard McAdams gives the example of norms being generated and enforced by a centralized private organization, such as a diamond exchange, as a matter of relatively formal, typically written, rules, as compared with groups or whole societies enforcing informal rules, such as the property norms that ranchers follow in Shasta County, California. ${ }^{76}$

Here, the policies and other mechanisms firms have adopted to address discrimination in the sharing economy are examples of centralized norms. But decentralized norms of nondiscrimination may also play quite a big role in shaping the development of the centralized norms adopted by firms. If decentralized norms of discrimination affect sharing-economy users' responses to these firms (i.e., if users' own strong antidiscrimination norms mean that they are less likely to use Uber if Uber fails to respond to concerns of discrimination $)^{77}$ then firms are of course motivated to comply with these decentralized norms of nondiscrimination.

Apart from whether these norms are generated and enforced in a centralized or decentralized manner, another point to clarify is whose norms these are, i.e., in which population they operate. Norms may govern the behavior of particular

74 Richard H. McAdams, The Origin, Development, and Regulation of Norms, 96 MicH. L. REv. 338, 340 (1997).

75 See id. at 351.

76 See id. (citing the work of Lisa Bernstein and Robert Ellickson respectively for these two different examples).

77 For a relevant example, consider the example of the Uber boycott for its CEO Travis Kalanick serving on President Trump's economic advisory council. See Julia Carrie Wong, Uber CEO Steps Down from Trump Advisory Council After Users Boycott, THE GUARDIAN (Feb. 3, 2017, 2:25 AM), available at https://www.theguardian.com/technology/2017/feb/02/travis-kalanick-delete-uberleaves-trump-council. 
groups, or they may govern the behavior of society as a whole. ${ }^{78}$ While antidiscrimination norms have certainly come a long way over the decades, there is still some lack of societal consensus over norms of antidiscrimination. This is certainly true for specific norms of antidiscrimination, such as sex discrimination in intimate spaces like bathrooms or a gynecologist's office, but, as recent political events have revealed, perhaps this is true for antidiscrimination norms more generally. ${ }^{79}$ Decisionmakers at sharing-economy firms generating and enforcing centralized antidiscrimination norms do tend to come from a particular demographic background (think wealthier, more educated, whiter, more coastal), perhaps calling into question the generality of these norms. ${ }^{80}$ And the customers who use their services (to whom firms may be disproportionately responding) also tend to come from a wealthier and more educated demographic. ${ }^{81}$

The remainder of this Section highlights a few of the most interesting facets of antidiscrimination norms in the sharing economy. Firms seem far more focused on discrimination by individuals against individuals rather than the role that the firm plays in generating the circumstances in which this discrimination arises. This is not true across-the-board, as the firms have sometimes focused on ways in which the firm enables discrimination. ${ }^{82}$ But it can be seen with the lack of focus on the way that certain core firm policies-like a ratings system-perpetuate bias. ${ }^{83}$ And it can be seen with the many charges of race and sex discrimination that have been lodged by corporate employees against the big sharing-economy firms, especially Uber. ${ }^{84}$ So even as these companies

78 See McAdams, supra note 74, at 386.

79 I am thinking of the rise of racist right-wing groups in the age of Trump.

80 Melanie Ehrendranz, Uber Hires a Much-Needed Diversity and Inclusion Officer, Gizmodo (Jan. 23, 2018, 1:45 PM), available at https://gizmodo.com/uber-hires-a-much-needed-diversityand-inclusion-office-1822340174. (reporting that Uber "is predominantly white and male, like the rest of Silicon Valley," and that "women make up less than a third of the company, with no black or Latinx employees in tech leadership").

81 Aaron Smith, On-Demand: Ride-Hailing Apps, Pew ReSEARCH Center (May 19, 2016), available at http://www.pewinternet.org/2016/05/19/on-demand-ride-hailing-apps. (finding that ride-sharing riders tend to be younger, wealthier, more educated, and more liberal than the general population).

82 See supra notes 40-42, 46-47 and accompanying text (discussing how Airbnb responds to discrimination); supra note 51 and accompanying text (discussing blind-matching of riders and drivers on Uber).

83 See Alex Rosenblat et al., Discriminating Tastes: Uber's Customer Ratings as Vehicles for Workplace Discrimination, 9 POL'y \& INTERNET 256 (2017).

84 Reuters, Uber Sued for Alleged Racial, Gender Discrimination, FonTunE (Oct. 25, 2017), available at http://fortune.com/2017/10/25/uber-sued-alleged-racial-gender-discrimination/. 
deploy strict nondiscrimination polices that apply to their users, they themselves may be perpetuating the discrimination of others or discriminating themselves in myriad ways.

This highlights how antidiscrimination norms in the sharing economy differ from antidiscrimination law. In at least one way, these norms seem to extend further than antidiscrimination law. The nondiscrimination policies of sharingeconomy firms bar individual workers and customers from discriminating against each other. ${ }^{85}$ The law, on the other hand, has yet to regulate discrimination by individual customers against workers, or by individual workers against customers, unless it also leads the regulated firm to violate the law. ${ }^{86}$

In other ways, antidiscrimination norms in the sharing economy mirror features of antidiscrimination law. Take the distinction between race and sex discrimination. Both antidiscrimination norms and antidiscrimination law take a stricter approach to race discrimination than sex discrimination. As a matter of antidiscrimination law, the Constitution scrutinizes race discrimination more rigorously than sex discrimination. ${ }^{87}$ Federal public accommodations law bans discrimination on the basis of race but not sex. ${ }^{88}$ Employment discrimination law contains a bona fide occupational qualification exception for sex but not race. As I have discussed before, many of these distinctions are most relevant in intimate contexts. ${ }^{89}$

Antidiscrimination norms in the sharing economy are likewise more deferential to sex than race discrimination. Airbnb expressly treats race and sex differently in intimate contexts. When shared living spaces are involved, hosts and guests may discriminate on the basis of sex but not race. ${ }^{90}$ In some ways, the different treatment of race and sex by antidiscrimination norms seems to

85 See supra notes 26-27, 31 and accompanying text (noting also exception permitting sex discrimination in shared living spaces on Airbnb).

86 See Katharine T. Bartlett \& Mitu Gulati, Discrimination by Customers, 102 IowA L. REv. 223, 225 (2016).

87 See Naomi Schoenbaum, The Case for Symmetry in Antidiscrimination Law, 2017 WIS. L. REv. 69, 79 n. 37.

8842 U.S.C. § 2000a(a) (“All persons shall be entitled to the full and equal enjoyment of the goods, services, facilities, privileges, advantages, and accommodations of any place of public accommodation, as defined in this section, without discrimination or segregation on the ground of race, color, religion, or national origin.").

89 See Schoenbaum, supra note 8, at 1064-65.

90 See supra notes 28-29 and accompanying text. Interestingly, though, the exception does not extend to sexual orientation. I have written previously about the reasons behind the permission for sex discrimination in intimate spaces and posited that one such force was concerns about unwanted sexuality. See Schoenbaum, supra note 8, at 1042-43; Heteronormativity in Employment Discrimination Law, 56 WASHBURN L.J. 245 (2017). But Airbnb's policy, which permits discrimination on the basis of sex while banning discrimination on the basis of sexual orientation, must be 
extend further than it does under antidiscrimination law. Firms have relied on sex segregation and sex discrimination to address concerns of sexual assault and sexual harassment in ways that the law likely would not cognize. ${ }^{91}$ While sex-segregated firms have given way to a simple ability to choose based on sex, the fact that sex-matching between worker and customer is considered a plausible option and race-matching between worker and customer is not reflects a far looser antidiscrimination norm on the basis of sex than on the basis of race-at least when it comes to sex discrimination as classification.

\section{Other Forces of Law}

Law can shape norms. ${ }^{92}$ This means that law can accomplish its goals indirectly, by changing underlying attitudes and preferences, rather than by directly regulating behavior. Law can play this role through a number of mechanisms.

The law can express values, which can influence behavior. ${ }^{93}$ One way of the law expressing value is by changing the social meaning of conduct. ${ }^{94}$ Professor Larry Lessig has described how this occurred in the context of antidiscrimination law. Prior to the passage of the Civil Rights Act of 1964, if a firm were to serve or employ black people, they were doing so voluntarily, and this meant either that the firm was greedy (by angling for more business or hiring at lower wages) or a sympathizer. This social meaning was dangerous for firms, as it might alienate white customers and workers. ${ }^{95}$ After the passage of the Civil Rights Act, serving black customers and hiring black workers was mandated, and removed the old

grounded in other interests, such as comfort, safety, or a desire for more (non-sexual) intimacy. See Schoenbaum, supra note 8, at 1038-46.

91 See supra note 59-68 and accompanying text. Although one Supreme Court precedent does allow sex to serve as a BFOQ in response to safety concerns, there are reasons to think this reasoning would not apply here. See Schoenbaum, supra note 8, at 1064.

92 See, e. g. McAdams, supra note 74, at 349; Janice Nadler, Expressive Law, Social Norms, and Social Groups, 42 L. \& Soc. INQUIRY 60, 72 (2017) (recognizing "the ways in which social norms and law mutually influence each other"). There is a vast literature on the interaction between law and social norms. The treatment here only ever so slightly skims the surface. My goal is merely to provide the most modest of introductions for those uninitiated to the field.

93 See generally Cass R. Sunstein, On the Expressive Function of Law, 144 U. PA. L. REV. 2021 (1996); Kenworthey Bilz \& Janice Nadler, Law, Moral Attitudes, and Behavioral Change, in THE OXFORD HANDBOOK OF BEHAVIORAL ECONOMics AND LAW 241 (Eyal Zamir \& Doron Teichman eds., 2013).

94 See Lawrence Lessig, The Regulation of Social Meaning, 62 U. CHI. L. REV. 943, 965-67 (1995); Sunstein, supra note 93, at 2043-44.

95 See Lessig, supra note 94, at 965-67. 
meaning from this conduct. In this way, law can change not only the social meaning of the conduct, but also our moral evaluation of those who engage in the conduct. $^{96}$

Law can also serve more material functions in changing norms. In a law and economics framework, law expands the choice set in markets of norms. ${ }^{97}$ Law can also serve information and coordination functions. ${ }^{98}$ As for information, legal rules can cause individual citizens to update their beliefs, because law provides new information. ${ }^{99}$ For example, new law can signal a change in attitude. Law can also provide information not only of social approval or disapproval of particular conduct, but of a societal calculus of costs and benefits. ${ }^{100}$ Law facilitates coordination by serving as a focal point for conduct and decisionmaking. ${ }^{101}$

Scholars have noted how antidiscrimination law has been especially important in changing norms of discrimination. ${ }^{102}$ While the exact role has been debated, ${ }^{103}$ scholars have provided some convincing data and examples to support this notion. For example, Professors Kenworthy Bilz and Janice Nadler highlight the quite stark turnaround in norms relating to sexual harassment of women in the workplace after the law began to recognize it as a form of sex discrimination. ${ }^{104}$ We can see this in the generally quite outraged reactions to current revelations of sexual harassment by high-profile men, even where the conduct would not be unlawful, because, for example, there is no employeremployee relationship. Despite the fact that law is not regulating, it seems that sexual harassment law has helped to generate norms of how we expect men to treat women with whom they have business relationships. As Bilz and Nadler explain, law can be especially effective at shifting norms when the regulation

96 See id.

97 See Robert C. Ellickson, The Evolution of Social Norms: A Perspective from the Legal Academy, in SocIAL NoRms 35 (Michael Hechter \& Karl-Dieter Opp eds., 2001).

98 See Richard McAdams, THE EXPRESSive Powers of LAW 6, 9 (2015).

99 See id.

100 See id.

101 See id. at 8-9.

102 See, e.g. Sunstein, supra note 93, at 2044, 2052.

103 Compare John J. Donohue III, Prohibiting Sex Discrimination in the Workplace: An Economic Perspective, 56 U. CHI. L. REv. 1337, 1338-39 n.6 (1989) (arguing that law has played a key role in shifting our attitudes toward nondiscrimination, and, in particular, toward incorporating women fully and equally into the workplace), with Richard A. Posner, An Economic Analysis of Sex Discrimination Law, 56 U. CHI. L. REV. 1311, 1321-25 (1989) (arguing that sex discrimination in the workplace would have declined significantly without the force of law, and citing "no evidence of large [positive] effects" of law on the position of women in the workplace).

104 Bilz \& Nadler, supra note 93, at 241-43. 
changes attitudes about the underlying morality of behavior, as we can suspect might have happened in the context of sexual harassment. ${ }^{105}$

In the circumstances of antidiscrimination norms in the sharing economy, we can see a few especially interesting ways in which antidiscrimination law has played a role in shaping antidiscrimination norms precisely because there is a domain of law relevant to the transactions at issue, even if it doesn't apply to these transactions. First, sharing-economy firms have adopted antidiscrimination law-even when it doesn't apply-as the baseline for acceptable conduct. Uber bars its users from discriminating on the basis of a list of characteristics, as well as "any other characteristic protected under applicable federal or state law."106 Airbnb requires that its hosts "familiarize [them]selves with all applicable federal, state, and local laws that apply to housing and places of public accommodation." In this way, law may be incorporated expressly into antidiscrimination norms.

Second, even when sharing-economy firms don't adopt the legal standard, we can sometimes see law being used as a yardstick. Firms may rely on a comparison of their policies with legal standards (whether they apply or not) as a signal of the strength of their antidiscrimination policies. For example, Uber has advertised its safety standards as going beyond what the law requires in terms of background checks for drivers in the cognate taxi industry. And Airbnb has advertised its nondiscrimination policy as "stronger than what is required by law."107 So at the same time these firms claim not to be regulated by law, they rely on law to convey that their policies and practices are adequate and perhaps even superior to law. Notably, in both the baseline and yardstick conditions, law is providing a floor for antidiscrimination norms, which firms sometimes exceed. ${ }^{108}$

105 See id. at 241 ("II]f laws change moral attitudes, we reduce-maybe drastically-the need for the state to act on or even monitor regulated players."). Once we recognize the interaction between law and norms-both how law can shape norms and how norms can shape law-there is a chicken-and-egg problem: which came first, the law or the norm? We can imagine that at least in some circumstances, there may be a positive feedback loop operating between law and norms. The norms change enough for there to be a change in the law, which in turn fuels more norm change, and so on.

106 See Uber, supra note 31.

107 See Murphy, supra note 2, at 11; id. at 20 ("The new policy requires Airbnb hosts and guests to do significantly more than merely follow applicable laws."); id. at 28 ("While hosts are required to follow all applicable laws that prohibit discrimination based on such factors as race, religion, national origin, and others listed below, we commit to do more than comply with the minimum requirements established by law.”);

108 Note that equality is not always a unidirectional vector. Sometimes the antidiscrimination rights of some (e.g. gay and lesbian customers) presses (or are at least claimed to press) on the 
Third, the existence of a relevant area of antidiscrimination law, even if it doesn't regulate discrimination in the sharing economy, legitimates government oversight of discrimination in the sharing economy. For example, after the release of research finding discrimination in the ride-sharing sector, Senator Al Franken sent letters to Uber and Lyft asking questions about concerns of discrimination raised by this research. ${ }^{109}$

Finally, the filing of discrimination lawsuits against sharing-economy firms serves several functions, even when the law doesn't apply. ${ }^{110}$ These lawsuits may help to underscore the morally troubling meaning of discriminatory conduct in the sharing economy. ${ }^{111}$ While individual sharing-economy users have complained of norm violations without law, ${ }^{112}$ the filing of the lawsuit and the invocation of antidiscrimination law ${ }^{113}$ make the moral dimension of the discriminatory conduct, and the societal consensus around it, far more salient. ${ }^{114}$ This is especially so because of the moral dimension of antidiscrimination law. ${ }^{115}$

Such lawsuits also help to provide publicity needed for the development, enforcement, and reinforcement of norms. ${ }^{116}$ As Professor McAdams has explained, publicity is important to the development of norms because it makes sure that two other conditions of norm development-consensus around the norm and risk of detection of norm violation-are known to the relevant community. The filing of discrimination lawsuits in the sharing economy appears to have served these functions. ${ }^{117}$ The filing of the lawsuit makes the

antidiscrimination rights of others (e.g. religious service providers). See, e.g. Masterpiece Cakeshop, Ltd v. Col. Civil Rights Comm'n, 138 S. Ct. 1719 (2018).

109 See Franken Letter, supra note 38.

110 See supra notes 11-12, 15 and accompanying text (citing such lawsuits).

111 See supra notes 93-95 and accompanying text (discussing how law can affect the meaning of conduct).

112 Maggie Penman \& Shankar Vedantam, \#AirbnbWhileBlack: How Hidden Bias Shapes the Sharing Economy, NPR (Apr. 26, 2016, 12:10 AM), available at https://www.npr.org/2016/04/26/475623339/airbnbwhileblack-how-hidden-bias-shapes-the-sharing-economy. (discussing the Twitter hashtag \#AirbnbWhileBlack used by those who felt that they had experienced race discrimination on the platform).

113 See supra notes 11-12, 15 and accompanying text (citing antidiscrimination lawsuits filed against sharing-economy firms).

114 See MCADAms, supra note 98, at 3 (discussing how law serves the function of expressing moral consensus around a norm).

115 See Bilz \& Nadler, supra note 93, at 241.

116 See MCADAMS, supra note 74, at 362 (discussing the role of publicity in the development of norms).

117 See, e.g. supra notes 11-12, 15 (citing articles reporting on these lawsuits). 
norm violation public, which helps to enforce the norm by making a penalty for the violation more likely. While the rise of social media has meant that individuals can publicly surface norm violations without law, ${ }^{118}$ the filing of a lawsuit makes mainstream media coverage more likely, ${ }^{119}$ which brings broader publicity and greater salience and veracity to the norm violation. Airbnb's decision to take more substantial action against discrimination on its platform followed shortly on the heels of a race discrimination lawsuit filed against the firm. ${ }^{120}$ The plaintiff in that case claimed that the Airbnb did nothing after he complained directly to the firm, suggesting that the lawsuit itself was significant in prompting action. ${ }^{121}$

\section{Implications}

This Part considers some of the benefits and costs of the fact that thus far the regulation of discrimination in the sharing economy has been largely left up to norms rather than the force of governing law. This Article offers only a brief survey of a select set of implications, and thus refrains from reaching any concrete conclusions, preferring instead to highlight some primary areas of contention.

As an initial matter, regulating behavior through norms is cheaper than regulating through law. ${ }^{122}$ When the cost of legal regulation is especially high, such as in the context of regulating discrimination by individual customers, where we might think it undermines autonomy, ${ }^{123}$ the role of norms may be especially important. This highlights how, when we are thinking about whether the law should regulate discrimination in a particular context, we should recognize that the relevant comparison is not law or no law, but law or norms, as norms will often be operating. This also means that when we consider whether

118 See Penman \& Vedantam, supra note 112.

119 See supra notes 11-12, 15 and accompanying text (discussing media coverage of antidiscrimination lawsuits against sharing-economy firms).

120 See Benner, supra note 11 (linking Airbnb's adoption of rules to fight discrimination by its hosts to the filing of the lawsuit, among other events).

121 See Hope King, Airbnb Sued for Racial Discrimination, CNN (May 18, 2016, 4:56 PM), available at https://money.cnn.com/2016/05/18/technology/airbnb-lawsuit-discrimination/ index.html.

122 See Nadler, supra note 92, at 72.

123 See Bartlett \& Gulati, supra note 86, at 238-39. 
to regulate discrimination in a particular area, we should think about the spillovers for norms as (typically) one of the benefits of regulation.

Despite these benefits, relying on norms rather than law raises a number of concerns. When we rely on centralized norms put forth by sharing-economy firms, firms are able to pick and choose their responses. We will be more or less concerned about this depending on the strength of decentralized antidiscrimination norms. To the extent that these decentralized norms mean that a firm that fails to take action to combat discrimination would lead to a loss of business, even firms acting purely out of self-interest will be motivated to take antidiscrimination measures. ${ }^{124}$ But even when decentralized antidiscrimination norms are strong, these will not typically be enough to ensure adequate antidiscrimination actions by firms, as the public will not have enough information to sanction norm violations by firms.

Discrimination is an area where we typically want to push for forward progress, and not simply retain current norms, as one role of antidiscrimination law has been societal transformation. We see mixed evidence as to whether norms are leading or lagging law in the context of discrimination in the sharing economy. On the one hand, norms lead law in that they regulate discrimination by individual workers and customers that the law generally would not touch. ${ }^{125}$ On the other hand, norms lag law in that they appear to approve or at least permit sex discrimination and perhaps even sex segregation that the law would not tolerate. ${ }^{126}$ In the era of Trump, we might be especially concerned that antidiscrimination norms, particularly in some places, have not come as far as we think.

Some fans of the market might argue that firms are more responsive to societal norms than lawmakers, as the market provides strong incentives to respond. But the question is to whom these firms are responding. Firms will be more inclined to respond to those who make up their user base rather than to society as a whole. Moreover, firms are not subject to the same level of transparency or scrutiny as public regulators, which leads to shortcomings in the public's ability to sanction norm violations. ${ }^{127}$ And when norms fail, there is no

124 I am agnostic as to whether firms here are acting out of genuine concern for discrimination or out of economic self-interest and only try to disentangle the two where relevant. This recalls the debate in moral philosophy as to whether altruism is really altruism if acting altruistically brings the actor utility.

125 See supra note 85 and accompanying text.

126 See supra note 91 and accompanying text.

127 See of course the seminal Ronald Coase on transactions costs, of which information costs are one. The Problem of Social Cost, 3 J.L. \& ECon. 1 (1960). 
guarantee as to the remedies or the process that is due in enforcing these norms (except as a matter of private contract). ${ }^{128}$

And, importantly, it's not just law that shapes norms, but also norms that shape law. Thus, we must consider how norms established by sharing-economy firms shape our antidiscrimination law. Scholars have noted how firm policies can shape juridical conceptions of the proper interpretation and application of antidiscrimination law, and this is probably true at the legislative level as well. ${ }^{129}$ We might imagine that firm responses can have an especially strong impact on law when firms are the first movers in regulating these areas, and when the type of conduct being regulated is new, such that firms are not acting to displace a preexisting norm, but are generating norms from the ground up. ${ }^{130}$ But the impact might not be limited to the sharing economy. If more permissive antidiscrimination norms are accepted in the sharing economy, this might have spillover effects to the regulation of the traditional economy. For example, if sharing economy firms sex segregate, this may start to seem more acceptable in the traditional economy as well.

One concern then is that firms might adopt antidiscrimination mechanisms that are out of sync with the types of goals typically embodied by antidiscrimination law. We can see this quite clearly with firms' efforts to address safety concerns that are perceived as "women's" problems with sex segregation. ${ }^{131}$ Another example comes with the depersonalization mechanisms discussed above, which sometimes rely on making decisionmakers blind to protected traits to disable their ability to discriminate, a strategy that I refer to as "ignorance as equality."132 Ignorance might not be as effective as it appears at first blush. For

128 In reality, even legal enforcement mechanisms are limited by arbitration clauses. See sources cited supra note 12 .

129 See Lauren Edelman et al., When Organizations Rule: Judicial Deference to Institutionalized Employment Structures, 117 Am. J. Sociol. 888 (2011); Linda Hamilton Krieger et al., When "Best Practices” Win, Employees Lose: Symbolic Compliance and Judicial Inference in Federal Equal Employment Opportunity Cases, 40 L. \& SOC. INQUIRY 843 (2015). We can imagine this would be true at the legislative level if for no other reason than factors like status quo bias.

130 See Ring, supra note 70.

131 See United Auto Workers v. Johnson Controls, 499 U.S. 187 (1991) (holding that excluding fertile women from certain jobs based on concerns of fetal safety violated Title VII). But see Dothard v. Rawlinson, 433 U.S. 321 (1977) (holding that excluding women from contact position in prison did not violate Title VII because of safety concerns it created, both for the prisoners and for the women workers themselves). For a critique of sex segregation as a means to address safety concerns in the sharing economy, see Schoenbaum, supra note 8, at 1056-57.

132 See generally Naomi Schoenbaum, Ignorance as Equality (manuscript in progress) (discussing and critically engaging the trend by both private firms and in the law of relying on ignorance to prevent discrimination). 
example, Innclusive, the anonymous alternative to Airbnb, says it "removes the opportunity for bias" by making guests anonymous, but it still relies on ratings, ${ }^{133}$ which may be infected by bias. ${ }^{134}$ Moreover, ignorance as equality robs decisionmakers of their capacity as full moral agents capable of exercising meaningful choice. This approach thus diminishes the educative function of antidiscrimination mechanisms. And relying on ignorance to achieve equality also places a burden on those who believe they are likely to be discriminated against to hide who they are, ${ }^{135}$ and to opt in to less intimate versions of a transaction to avoid discrimination, even if this is not their preference. ${ }^{136}$

Still further, the costs of ignorance as equality may be precisely to the unique value that the sharing economy brings in terms of the generally more intimate nature of the transactions it offers as compared with the traditional economy. ${ }^{137}$ There are costs to both workers and consumers of reducing the intimacy of sharing-economy transactions based on the utility that intimacy provides, in terms of promoting the efficiency of the transaction, and even for the simple reason that some users prefer the intimacy that the sharing economy can afford. ${ }^{138}$ Some sharing-economy firms have resisted further shifts towards anonymity for these reasons. ${ }^{139}$ And we could even imagine that reducing intimacy might undermine efforts to combat discrimination, as the more personal nature of sharing-economy transactions could be harnessed to enhance enforcement of antidiscrimination norms. ${ }^{140}$

133 See Ellen Powell, How Can the Gig Economy Address Discrimination? Christian SCI. Mon. (Nov 2, 2016), available at https://www.csmonitor.com/Business/2016/1102/How-can-the-gigeconomy-address-discrimination.

134 See Alex Rosenblat et al., Discriminating Tastes: Uber's Customer Ratings as Vehicles for Workplace Discrimination, 9 POL'Y \& INTERNET 256 (2017). Or there may be discrimination after guests arrive at the lodging, such as neighbors calling the police out of concern that black Airbnb guests were criminals. See Alison Griswald, The Dirty Secret of Airbnb Is That It's Really, Really White, QUARTZ (June 23, 2016), available at https://qz.com/706767/racist-hosts-nothotels-are-the-greatest-threat-to-airbnbs-business/.

135 See Murphy, supra note 2, at 23 (explaining that "guests should not be asked or required to hide behind curtains of anonymity when trying to fnd a place to stay" and that "[t]echnology can bring us together and technology shouldn't ask us to hide who we are").

136 See Katie Benner, supra note 11 (quoting Professor Jamila Jefferson-Jones as worrying that "[i]f mainly minorities feel comfortable in using instant bookings to reserve rentals on Airbnb, for instance, that could end up creating a two-tiered reservations system").

137 See Schoenbaum, supra note 44, at 466-69.

138 See id.

139 See supra notes 49-50 and accompanying text.

140 This is because of the role that the loss of esteem plays in enforcing norms, which one could imagine is made all the more effective the closer the relationship. See McAdams, supra note 74 , at 364 . 
A final concern with firms' antidiscrimination measures is perhaps the most troubling: that sharing-economy firms are adopting antidiscrimination measures precisely in order to avoid legal regulation. Without these measures, there might be public outrage in response to concerns of discrimination and pressure to apply antidiscrimination law here. These antidiscrimination measures may allow the firms to have it both ways: to quell public concern about discrimination without the expense and burden of regulation by antidiscrimination law.

\section{Conclusion}

The focus on regulating discrimination in the sharing economy has been on whether antidiscrimination law does or does not apply. This overlooks the way that antidiscrimination norms can operate even without applicable antidiscrimination law. This Article has examined how antidiscrimination norms can regulate discrimination in the sharing economy even in the absence of direct legal regulation, and has considered the role that antidiscrimination law plays in this phenomenon, even when it does not directly regulate. While antidiscrimination norms may sometimes be ahead of antidiscrimination law in combatting harmful forms of discrimination, other times antidiscrimination norms may lag behind the law or be mismatched with its goals, and may suffer from lack of enforcement. This Article ultimately provides a case study of the state of our antidiscrimination norms and their relationship to antidiscrimination law that can serve as a foundation for thinking about future regulation of the sharing economy.

Acknowledgements: My thanks for very helpful comments and questions go to Naomi Cahn, June Carbone, Shelly Kreiczer-Levy, Nancy Levit, an anonymous reviewer, the editors at the Journal of Law and Ethics of Human Rights, and participants in the symposium on the Sharing Economy: Markets and Human Rights at the College of Law and Business in Ramat Gan, Israel. 